\title{
FROM THE SEARCH FOR AN ORIGINAL AFRASIAN HOMELAND TO THE PROBLEMS OF SEMANTIC RECONSTRUCTION: A RESPONSE TO COMMENTERS
}

Keywords: genealogical classification, glottochronology, comparative and historical linguistics, lexical reconstruction, proto-language, Afrasian (Afroasiatic), Indo-European languages, weaponry, warfare.

\begin{abstract}
The article is the author's appreciative response to three colleagues who commented critically on the lead article ("Lexical Reconstruction for the Reconstruction of Prehistory: ProtoAfrasian Terms Related to Weaponry, Warfare and Other Armed Conflicts"). It focuses on problems of genetic classification, glottochronology, and ancestral home of the Afrasian (AfroAsiatic) language macrofamily (response to A. M. Kozintsev); phonetic and semantic criteria of lexical comparison in the reconstruction of proto-language cultural terms, their representativeness in different branches of the language family and the distinction of the original vocabulary from the borrowed. It also touches upon the comparative quality of Afrasian and Indo-European reconstruction considering the large numbers of scholars working in the general area of IndoEuropean studies versus a few active specialists in the field of comparative historical Afrasian studies (responses to G. S. Starostin and A. V. Dybo).
\end{abstract}

This article is a translation of: Милитарев А.Ю. От поиска прародины до проблем семантической реконструкции: ответ оппонентам // Etnograficheskoe Obozrenie. 2021. No 4. P. 63-78. DOI: 10.31857/S086954150016699-8

First of all, I would like to express my gratitude to the three colleagues who responded to the invitation of the exceptionally friendly editorial board of the "Ethnographic Review" to give their comments on my article. Such attention to other people's work is especially touching in this pragmatic and egocentric age. The result was not just comments and expert assessment with an analysis of material, which is very useful per se, but three full-fledged articles containing valuable theoretical and methodological provisions, which clearly go beyond the scope of proposed discussion.

Comments by $\boldsymbol{A}$. $G$. Kozintsev and $m y$ responses. I shall start with the comments by Aleksandr Grigoryevich Kozintsev devoted not to the narrow topic of my article, but to disputable problems of Afro-Asiatic classification, chronology and ancestral home. They are exceptionally useful for me and, I hope, for the readers, especially in the part where extralinguistic data are presented and interpreted: I do not fully trust my own understanding and interpretation of genetic, archaeological and odontologic materials, so the analysis of an anthropologist with the broadest outlook makes many things clear to me, not to mention the fact that I was not familiar with many fragments of the picture, described by A. G. I was somewhat amused, however, by the characteristic of me as of "the most influential supporter" of the West Asian homeland: the representatives of the mainstream are influential, but I always stood somewhat aside, and I think, the people influenced by me

Alexander Militarev | https://orcid.org/0000-0002-5684-3053 | amilitarev@gmail.com | Russian State University for the Humanities (6 Miusskaya Square, Moscow, 125267, Russia)

Etnograficheskoe Obozrenie. 2021. № 4. P. 284-297. https://doi.org/10.31857/S086954150016800-0

(C) Russian Academy of Science | (C) Institute of Ethnology and Anthropology, RAS

ISSN 0869-5415 | http://journal.iea.ras.ru 
may be counted on the fingers of one hand. Yes, there was a period in the international AfroAsiatic linguistics, when I. M. Dyakonov and, in some degree, A. B. Dolgopolsky led the way, but this was before the era of "internet PR"; nowadays, the mainstream in comparative Afro-Asiatic linguistics (and extralinguistic problematics related to it) is represented by C. Ehret and R. Blench, as judged by the abundance of references to their work and opinions regarding all issues. I shall cite A. G. Kozintsev and comment on his words:

AK: An active advocate of the African homeland theory is C. Ehret. He ascribes a considerable ideological significance (emphasis added - A.M.) to this idea, since, in his opinion, it forces us to discard the long-standing prejudice that the ancient history of North Africa was only a reflection of the history of Western Asia. Ehret estimates the antiquity of the AA macrofamily at 15 thousand years, and places its homeland in the Horn of Africa. $<\ldots>$. The position of H. C. Fleming (Fleming 2006: 140-142) and R. Blench (Blench 2006: $159-160)$ is rather similar... A generally positive attitude to Ehret's theory was expressed by G. S. Starostin (Starostin 2017: 226).

AM: G.S. Starostin says the following:

... the intuitive opinions of many scientists, including Christopher Ehret, whose Afro-Asiatic concept is compatible with the African one, but not with the Asian ancestral homeland with the subsequent migration of the Semites to Asia...; according to Ehret, "there are no words in the Proto-Afrasian vocabulary indicating cattle breeding or cultivation of crops" (Ehret 2000: 290-291)... It should be borne in mind that Ehret's statement is based on his own Proto-Afrasian reconstruction (Ehret 1995), which is frequently criticized on methodological grounds...

(Starostin 2017: 226).

To finish with this incidental subject I will try to explain my attitude to "Ehret's theory" and to R. Blench's position. Both authors have really collected priceless field materials in many African languages, but they present themselves as primarily comparative linguists: in this case their opinion - like mine - on genetic or archaeological issues may only be interesting to readers of popular media. The position, and especially the theory, which relates to localization of ancestral homeland of a linguistic family, shall, first of all, present corresponding linguistic arguments - names, including reconstructed proto-language ones, of animals, plants, terms that shed light on ecology and culture; and there is no other method than glottochronology to establish the chronology of branching of any linguistic family, irrespective of any ones' opinion of it.

And only after obtaining the results, even just preliminary, of these operations, it makes sense to compare them with extralinguistic data - preferably relying on specialists in the relevant fields rather than on one's own idea of them. Unfortunately, neither G. K. Fleming, nor Ch. Ehret, nor R. Blench relied on any representative selection and reconstruction their own or someone else's - of the above-mentioned terms, not to mention glottochronology, and neither of these authors had such an opportunity, not possessing necessary established comparative methodology and technique (see the extremely soft, "politically correct" assessment of Proto-Afro-Asiatic reconstruction by Ch. Ehret above in G. S. Starostin's quotation). The rest - "intuitive opinions", "theories", "conceptions", "statements", particularly their ideological significance, are, in my opinion, of little value.

In order to prove my point I'll give some examples, showing why I cannot take seriously the etymology and reconstructions of Ch. Ehret, who compares nes $a$ S a "cow's vagina" in a South Cushitic language with igwaŝú "jaw" in another one (logic suggests that the meaning in the common proto-language should be vagina dentata?) or didaw "lion" in one language with did- "to remember" in another one with a reconstructed ancestor meaning "to stare"; or pa?asuko "lungs" in one language with lupa?é "curse" in another one with a reconstucted meaning "spit"; or in Nilo-Saharan languages: * $b \varepsilon b>$ > Uduk "large amount", Sai "wide", 
Mabaan "long", Ik "puff adder" vs. Kunama "lard" with the explanation "wide" > "fat" > "fat (n.)" (Ehret 2001).

The same applies to another author mentioned above, R. Blench, who publishes a great variety of texts full of diverse, sometimes valuable information on the history of all periods, archaeology, genetics of various peoples, on the languages of different families and continents, but who, at least in the Afro-Asiatic area, compares random things - without semantic whims, though - by phonetics (his idea that Chadic languages originated from Cushitic is just another opinion based, apparently, on intuition). Just a couple of first available examples ${ }^{2}$, which are quite characteristic - Canarian names of cereals: te-zzez-es in the language of Hierro (with the Spanish plural suffix -es) "barley or wheat" (actually from the Afro-Asiatic *zaw-/*3iz- "wheat", cf. Akkadian $z \bar{l} z-u$ "Emmer", Egyptian zw.t "Weizen", West Chadic * $z W w / y$ - "guinea corn", etc.) is compared with unrelated ta-moz-en "barley" in the languages of Gran Canaria, Lanzarote and Fuerteventura (actually from BerberCanarian pl. *ta-mVz-in id.). Here are comparisons of zoonyms: Tenerife ara "goat" (actually from the Afro-Asiatic *?araw/y- "k. of small bovid", cf. Semitic: Mehri ?ari-t "shegoat", East Chadic: Lele ore "goats", Cushitic *2aray- "goat", etc.) compared with Berber ulli/welli "sheep, goats" (from the Afro-Asiatic *waGil- "k. of small bovid").

This is why I am not very interested in the opinions of these authors about the Afro-Asiatic ancestral homeland, the time of separation of one or another branch of this macrofamily, its genetic classification, etc. - as opposed to the arguments of, let us say, S.L. Nikolaev, my coauthor, in the recently published and forthcoming articles ${ }^{3}$, who places the Afro-Asiatic Urheimat to Eastern Sahel based on our list of PAA zoonyms, perhaps not quite complete, but close to this. His position, opposite to mine, is important and interesting to me, especially because besides being a highly quolified comparative linguist he is well familiar with palaeozoology; this position makes me search new materials and further substantiate the arguments in favor of my hypothesis. But argue against "opinions"...

No offense meant to A. G. Kozintsev, of course, who had to present various points of view in an unbiased manner, at least to complete the picture. With regard to his various tree models, the method itself seems quite promising to me, but the problem is that these models are based on 50-word Afro-Asiatic lists in The Global Lexicostatistical Database (which G. S. Starostin himself called "raw" in our correspondence), taken for granted, while in relatively short lexicostatistical lists, especially 50 -word ones, if you change them a little, you get a slightly different tree. No Cushitic-Chadic branch will be formed, of course, but the Omotic family may get separated from the Cushitic one, the Berber branch may result closer to Egyptian than to Chadic (the percentage of Berber-Chadic matches in both 50- and 100-word lists is only slightly higher than that of Berber-Egyptian matches); given that the fact of borrowing cultural vocabulary from Egyptian to Berber ${ }^{4}$ and Chadic, as well as between Berber and Chadic is undoubtful, we cannot exclude the possibility of at least one or two loan-words even in the 50 -word basic list. Let's add here the problem of choosing words for the diagnostic lists, especially in case of Egyptian (limiting the selection to one period, let us say, Middle Kingdom - also a long enough period of 300-400 years - will significantly reduce the amount of lexical items in the list), and it will become clear, how carefully these lists should be compiled. We agreed with A. G. Kozintsev to play with 50-word and 100-word AfroAsiatic lists and various types of trees someday.

AK: If we follow the requirements of a strictly phylogenetic (cladistic) taxonomy, such a similarity cannot serve as a basis for merging taxa. This contradicts the Western Asian homeland hypothesis because the homeland should be where the earliest branches had separated. There are two such branches here, the Omotic and the Cushitic, and both of them are located in North-East Africa. Can this possibly be the result of two successive migrations from the Levant?

AM: I think there is nothing seditious about the idea of two successive migrations from the Levant. The path that was once hypothetically traveled by the Cushomotic speakers (or 
successively by the Omots and the Cushites; the dating that I received for their separation 8,800 B.C., and my suggestions about their appearance in Africa in the 9-8 mill., are rather conventional, but it seems that they do not contradict each other), was 7-8 millennia later if, which is very likely, the Proto-Semites were divided in the Levant - partially traveled (to the south of Arabia) by the speakers of Proto-South Semitic (Proto-Mehri-Jibbali-Soqotri), then Proto-Ethiopic and, finally, Proto-Epigraphic South Arabian. The Proto-Ethiopians (perhaps with a small group of Sabaeans), apparently moved from there through Bab-elMandeb in the early first mill. BC. ${ }^{5}$

AK: Common AA words for dog, bow and arrows have been reconstructed (Militarev, Stolbova 2007). The dog is known to have been introduced to Africa from Western Asia (Bergström et al. 2020). Skeletons of dogs were found in Natufian sites (Clutton-Brock 2017: 13-15); there is evidence of dog domestication at an even earlier stage of the Levantine Epipaleolithic, in the Kebaran microlithic culture (Dayan 1994).

AM: About the bow and arrow see my discussed article: I have no doubts about the presence of words for them in the PAA. As far as the dog is concerned, it is linguistically more complicated; here are important comments by S.L. Nikolaev (from private correspondence):

The dogs are more interesting. The Semitic has its own new term for a domesticated dog (*klb - instead of the lost world and PAA * $k^{w}$ ihan- 'dog'), the scavenger - jackal/hyena - is the only term left from the rest of PAA roots:

Sem. *?away-: Hbr. *?̄̄ (pl. ?iyyīm) 'jackal' [Canis aureus] o Syr. bənāt ?away 'thoes, canes aurei' [C. aureus] ○ Arab. Pibnu-l-Pāwan 'animal regardé comme un mélange né d'un chien et d'un renard' o Tgr. ?aw 'eatable wild animals' ○ Amh. yäyi 'hyena' [Hyaenidae sp.], awu 'hyena's cry; hyena' [Hyaenidae sp.] o Gur.: Chaha, Gyeto, Ennemor, Muher awi 'wild animal, beast' (plus the barely preserved "wolf" Sem. *?aws-: Arab. ?aws-, pl. ?uways- 'wolf' [Canis lupus].)

The rest of the AA roots quantitatively and qualitatively correspond to the East-African fauna wolf, some species of foxes and jackals, African wild dog (L. pictus) and a couple of names for the hyena.

I do not quite agree that the Semitic * $k a l b$ - is a new term for a domesticated $\operatorname{dog}^{6}$, but the fact that the only common Semitic name for a dog containing the element $b$ with an unclear function corresponds to an Afro-Asiatic root with a vague meaning, and the rest of common Afro-Asiatic names for the dog are poorly represented in the Semitic languages, indeed, requires an explanation, without which the early domestication of the dog in the Levant says nothing about the Afro-Asiatic ancestral homeland: there is no reliable ProtoAfroasiatic - including the Semitic - term for the dog.

AK: There are also more specific contradictions between the lexicostatistical and genetic data. There is no explanation for the considerable genetic similarity between the Tuareg and the Beja (Cavalli-Sforza et al. 1994: 173).

AM: I venture to suggest one hypothetical explanation. I was never engaged in TuaregBedauye language contacts, but I dealt with Berber-Nubian language contacts (see Militarev 2020b) and I can confirm that a) Berberophones reached the area where the Nilo-Nubian languages were spread, not far from the Bedauye (Beja) speaking area; b) almost certain it was Garamantes; c) it is very likely that they passed through the Beja speaking area on their supposed route to the Omotic speaking area ${ }^{7}$; d) I'm convinced that the Garamantes are the linguistic, cultural (and most likely biological) ancestors of the Tuaregs ${ }^{8}$.

\section{Comments by G. S. Starostin and my responses.}

GS: *ma/itw- *may/wt- "club, cudgel"... the Egyptian parallel, although not perfect in terms of semantics (the Egyptian [emphasis added. $-A$.M.] $m d w$ staff was probably more sacral than a military tool). 
AM: Eg. $m d w(<* m t w)$ "Stab, Stock (auch als Waffe)". Seems like initially it was a stick used as a weapon (club, spear), but which had also a sacral and symbolic meaning, which remained both in the Egyptian and the ancient written Semitic languages - Akkadian, Ugaritic and Hebrew.

GS: The situation is much worse with the Chadic part of the etymology presented in one (hausa) of several hundred languages; in order for this parallel to be acceptable, it is necessary at least to show its reconstructability to the Proto-Chadic or at least to the ProtoWest Chadic level.

AM: Here is an addition to Chad. W.: Hausa múč́lyā, pl. mútàitai "stirring stick; long pole"; Gwandara màtá? "arrow" and "bow"; E.: Bidiya mèta "javelot, hampe de lance" (which partly overlaps with one of the supposed meanings of the Egyptian $m d w$ "walking stick, with knobbed end downward", см.: Takács 2008).

GS: The Cushitic part of the etymology consists of two languages - Oromo (Lowland East Cushitic), where we have mututẹ "club", and Sidamo (Highland East Cushitic), where the form amātt-o is used in the comparison... (what is initial $a$ - in Sidamo?..)

AM: The initial $a$ - in Sidamo is a non-productive (fossilized) prefix with an unclear, as in many other such affixes, semantics/function (Militarev 2005), cf. a form without $a$ - in Sidamo: mûta, pl. mûtța "small stick" and in Darasa: müt-iččo "leaf sheath of enset", and also HEC: Sidamo agoda "shoulder" vs. Burji gudum- $a$, Hadiya gudum-o "shoulder" (with another fossilized suffix $-(u) m)$.

GS: ...Secondly, even within Eastern Cushitic comparison is not perfect: "club" and "arrow" are objects that are semantically far from identical.

AM: It is not quite clear why the pair "club" and "arrow" is "worse" than the PIE pair *gweru "spear staff", or than ancient Greek khâio-s m., khâio-n n. "shepherd's crook" (unlikely to be lanced), root * $\hat{g} h a i s-o / e-s$ "throwing spear, dart" (from the verb * ${ }^{*} h h_{a} i$ "throw"?).

2. *kVs- "bow".

GS: ...at the proto-Semitic level, of course, the root *kaš-t- "bow" is reliably reconstructible (it is not very clear, however, how it is related to the Arabic kaws- ), but further comparisons are challenging. It is said about the Egyptian word k's that its original meaning most likely was "bowstring"; even if so, the semantic link between "bow" and "bowstring" is not as unambiguous as it may seem (synchronous polysemies of this kind are unknown to me).

AM: Synchronous polysemies would, perhaps, be more convincing, but the comparison of the Semitic *kVs- "bow" and the Egyptian $k^{3} s$ "bowstring" has a parallel in IE (see next).

GS: ...it is much more likely in this case that the original meaning was still the broad "to attach, tie" rather than the narrow "bowstring", let alone "bow".

AM: It is quite possible, but why does this exclude the derived meaning: from "tie" > "bowstring" > "bow" at the Proto-Afroasiatic level? Compare (from the examples provided by A. V. Dybo): PSIE * $g^{w} e y \bar{a}\left({ }^{*} g^{w} e y(e) h_{a}\right.$, Gen. $\left.{ }^{*} g^{w} i h_{a} o s\right)$ "bowstring": Old Greek bió-s m. "bow"; Ind.-Iran. Avest. jya "bowstring", Pers. zih "bowstring", Sanskr. $j(i) y \bar{a}$ "bowstring". \| PIE meaning is, sooner, "tendon, thread", compare: Celt. Cymr. pl. giau "tendons, nervs", Slav. *žicca "thread; yarn", Balt.Lith gija "base threads".

Or a similar case with different semantics: PIE *heksmo/eh ${ }_{a}$ " "spear": Balt. Old Prus. aysmis "skewer", Lith. iěšma-s, jiěšma-s "skewer, spear", Lett. iesms "skewer"; Old Greek aikhm $\ddot{\ddot{a}}$ "spear tip, spear". || Derivative of the verb * $h_{a} e k$ - "to wound with a sharp object".

GS: ... the dictionary by H. Jungraithmayr and D. Ibrishimov, where a a number of $k \varepsilon s \varepsilon$-type forms with appropriate meanings, found in a number of Eastern and Central Chadic languages, is defined as the result of borrowing from the Central Sudanic language 
Bagirmi, which is well known to have been a donor language for many languages of the Chadic family $<\ldots>$ the word kese in Bagirmi means exactly "arrow".

AM: The Chadologists, of whom, speaking from my experience, almost no one (except for O.V. Stolbova) knows how to build Chadic etymologies from Afro-Asiatic ones (hence is disposed to acknowledge them), have a peculiarity: they see borrowing either from Kanuri or from Bagirmi in many Chadic words - even where the term is much more plausibly explained by the proto-form in its group (which excludes the chronologically relatively recent influence of Kanuri or Bagirmi), not to mention the Afro-Asiatic parallels. This is a very typical approach for specialists in one language or a compact group of languages, who, not knowing how to compare them with distantly related languages, treat them as isolates; any word then one has to either etymologize from the same language (or closely related languages), or consider it borrowed. The forms of the majority of words quoted by O. V. Stolbova are, indeed, oddly alike (like kese) and, in theory, may be "bagirmisms", but it is not clear how kese "arrow" was borrowed from Bagirmi into a number of Chadic languages in the meaning of "bow" (see below). Perhaps, the secondary meaning "arrow" developed from "bow" in some Chadic language from which it was borrowed in Bagirmi; then, in the period, when Bagirmi became a "donor language for many languages from the Chadic family", this "arrow" was reverse borrowed from Bagirmi to other Chadic languages.

GS: ... from the extinct language Kwadza kasamato "bow", which is arbitrarily divided into components kasa- and -mato. Taking into account the fact that the component -to in Kwadza is a frequent noun suffix, a segmentation into kasama-to would be more acceptable, in which case this "bow" is hardly separable from the Proto-Western Rift paradigm *kasa:ma, pl. *kasamu "arrow" (Kießling, Mous 2003: 173). The only problem is that the initial consonant is voiceless (not ejective); perhaps it means that $k$ - was written in Kwadza incorrectly (this concerns a single extinct language as opposed to an entire group of living Western Rift languages - Iraqw, Alagwa, Burunge), but in this case the common South Cushite reconstruction should be *kasama-, and in this case this word cannot be cognate with other Afro-Asiatic forms with initial $k$-.

AM: Firstly, Kwadza kasamato is not arbitrarily divided into kasa-and -mato: not only -to is a suffix in Kwadza, but also - am is a suffix, apparently non-productive (fossilized), as in many other Afro-asiatic languages, cf. cat-am-uko "hair" vs. Dahalo tata "hair" (<*cat-), Omotic * sic- $(<*$ cit-) id.; Kwadza sasa?-am-o "star" < Afro-Asiatic *sasa?- id. ( $>$ West Chadic *sasuw-, East Chadic: Sokoro sessi, Mubi sôsúwá). Thus, the root in Kwadza is kas-. Secondly, in West Rift languages - am is a productive verbal and noun deverbal suffix (for example, Iraqw warq-aw- "turn around", warq-am-o "patch"; waS- "to flood", waS-am- "to flow, trickle", waS-am-u "well, wadi", but there also is an example of a non-productive one: Iraqw daaq and daq-aam "skin"), i.e. *kasa:ma may go up to *kasā-ma (perhaps, deverbal noun from missing verb "shoot [a bow]"). And, thirdly, there is khasama (kasama in the Afro-Asiatic transcription) "arrow" in the unpublished Hadza dictionary", which is an obvious Western Rif borrowing: there is a whole group of them in Hadza, however, mainly from the Iraqw language, where kasaamu means "knife", and kasmu - "arrows". However, this borrowed word is conveyed exactly with the ejective $k$, completely coinciding in consonantism with the Kwadza and common Afro-Asiatic forms. Here, G. S. Starostin's assumption "that $k$ - in Kwadza was written incorrectly (this is about a single extinct language, unlike a whole group of living Western Rif languages - Iraqw, Alagwa, Burunge)" may work in the opposite direction: all living Western Rif languages - Iraqw, Alagwa, Burunge (there is also Gorowa) - were recorded by the same people, while Kwadza and Hadza - definitely by different people, i.e. if we look for a mistake in the record, it is more likely to occur in the record of the Western Rif root.

3. * $d V g$ - "bow and arrow".

GS: The very meaning in the title of this etymological article raises doubts (how frequent and natural is the existence of a separate lexical root with a "common" meaning "bow and 
arrow"? - in all the provided materials such polysemy, apparently, is stated only for the Sidamo language and requires verification at the text level).

AM: There are many such cases in Afro-Asiatic languages, compare at least Central Chadic: Munjuk baraw "arrow", Musgu bárau "arrow, bow", Masa baraw-ta "bow"; or Central Chadic: Musgu kise "bow", Mbara kèsé "arrow", Eastern Chadic: Tumak kèské, Migama kêsè, Bidiya kēse "bow", Kwang kēsé, Sokoro kesć "arrow"; or Western Chadic: Gwandara màtá? "arrow" and "bow" ". Also compare (from IE materials provided by A. V. Dybo): PNIE* $h_{a}$ erkwos "bow arrow": Arc. Lat. arquus "bow", Lat. arcus "bow"; Germ.. *arhvō, Old North or "arrow", Old Eng. earh "arrow" (> modern Eng. arrow), Goth. arhazna "arrow"; and also (from "Tower of Babel" web-site): Proto-IE *teks- Meaning: weapons ("bow" and "arrows, spear"):

Other Iranian: NPers tax̌̌ "bow" (weapon). Old Greek: tókso-n "Bogen”, pl. "Schiesgerät(e), (Bogen und) Pfeile". Germanic: *oixs-ō(n-) f., *oixs-al-ōo(n-) f. "spear, axe". Latin: tēlum, $-\bar{l}$ n. "Fernwaffe, Wurfwaffe, Geschoss, Waffe überhaupt, Axt etc.", Russ. meaning: "weapon (bow and arrows, spear)".

In general, "verification at the text level" for languages without any written form or those which only recently obtained it is an exaggerated and obviously unrealizable requirement. Georgy Sergeevich, I'm afraid, has been slightly infected with the excessive skepticism of his mainstream "lamp" opponents, with whom he has been bravely and skillfully fighting for many years.

GS: ... this root most often has the verbal meaning "to bow, to bend", whereas the nominal meaning "bow" is often interspersed with the semantics of "angle" or "boomerang", which confirms the original verbal meaning "to bend".

AM: Why does it exclude the development of "bend" > "bow" > "arrow" already at the Afro-Asiatic level (see my arguments to point $2 * V_{S-}$ "bow")?

GS: ...H. Jungraithmayr and D. Ibrishimov, for example, suspect here a substrate element from the Niger-Congo languages.

AM: This is their complete right - to suspect; they need not even provide examples of source words from Niger-Congo languages (see my arguments to point $2 * k V s_{-}$"bow").

Here I would like to take the opportunity and reply to the critical remarks of $\mathrm{G}$. S. Starostin about my reconstructions of the supposed Proto-Afroasiatic agricultural terms, in particular, of the names of cereals, presented not in this discussion, but in another article:

«Most worrisome is the near-complete lack of terms for cultural plants with unambiguously determined semantics. The only such item is * $\hat{c} a r V y$ - 'barley', and even that is reconstructed based on Proto-Semitic * $\hat{s} a \uparrow V r$ - 'barley; grass, straw', with Ethiosemitic and Modern South Arabic reflexes usually restricted to 'grass, straw'; some scattered Chadic parallels meaning either 'yam' or 'okra'; and an alleged Proto-Cushitic *?aĉar, reflected as Beja ešerri 'maize' and as ašaru- 'barley' only in one East Cushitic language (Kambaata). The direct semantic isogloss is therefore confined to a few Semitic languages and one Cushitic language, making the semantic reconstruction 'barley' highly dubious. The degree of semantic lenience and topological scattering in other terms is even higher: for instance, *bar- 'a cereal' has the meanings 'wheat', 'maize', 'threshed grain', 'sorgho', 'yam', 'millet', 'ground nut', 'oats', 'stalk', 'straw' in daughter languages - clearly, a huge amount of low-level semantic reconstruction is necessary here to ascertain which of these reflexes deserve to be grouped together and which ones are the result of accidental phonetic resemblance» (Starostin 2017).

First of all, I think it is not all that bad. G.S. did not mention root *carVy- "barley" a very important term, presented in my paper: beside a common Sem. term it includes Eg. (MK) šr.t "barley", which cannot be a borrowing from the Sem. one due to phonetic reasons, and the presence of a term with the same meaning in two Afro-Asiatic branches makes the meaning "barley" in the proto-language term highly probable. The difference in meaning in other languages is not that big, if we add Cush. E.: Tembaro ašaru "barley" 11 and Chad. C.: Daba $\hat{z} o \dot{r} \bar{u}$ "k. of white corn", Mofu zarawáy "sorgho jaune sp." (to be fair, these Chadic 
terms were not included in the discussed paper - they were published after its publication). The same is with *bar- "k. of cereal". Probably, it was not necessary to provide all "secondary" terms like "culm", "straw" and, perhaps, "yam" and "nuts", but the main terms, derived from *bar- - common Semitic (in Hebrew, Sabaean, Arabic and Soqotri) "wheat", Berber "sorghum", Egyptian "k. of cereal", Chadic "k. of cereal" and "millet", East Cushitic "barley" and "oat", Southern Cushitic "grain" and "maize grains" (which gradually developed into "maize" in these and Omotic languages), - appear to me related to the proto-language via semantic shifts, associated with natural, historical and cultural peculiarities of each language community.

Secondly, speaking about the "level of semantic inaccuracy and topological scatter", let us refer to the Proto-Indo-European terms which mean cereals and are represented on the "Tower of Babel" web-site, which appears the most complete and advanced etymological data base for many world languages. The Indo-European subbase is compiled by one of the highest level modern comparativists - my friend and co-author S.L. Nikolaev and reflects the contemporary level of Indo-European linguistics. I'll provide all the material in a condensed form to save the space (Nikolayev n. d.):

Proto-IE: *bhar-; *bharəs- Meaning: a k. of cereals (millet, barley, spelt): Slavic: *bъrъ B D 'просо (Panicum miliacium)', 'бор раскидистый (Milium effusum)';

*boršbno. Germanic: *bar-ja- m.; *bariz-īn-ia- adj. Latin: far, gen. farris n. 'Dinkel, Spelt; Schrot, Mehl', farrāgō 'Mengfutter'; farīna f. 'Mehl'. Other Italic: Osk far, Umbr far 'far'; Umbr farsio, fasiu 'farrea'. Celtic: Cymr, Corn., Bret bara m. 'bread'. Russ. meaning: растение (злак - просо, ячмень, полба).

Proto-IE: *dhōn- Meaning: cereals, bread: Tokharian: B tāno ‘seed, grain'. Old Indian: dhānă f. 'corn, grain'; dhānyà- n. id.; adj. 'consisting or made of grain'. Avestan: dānokarša- 'eine Ameisenart'. Other Iranian: NPers dāna 'Korn'. Baltic: *dôn-â (1), *dôniã (1) f. Russ. meaning: зерно, хлеб.

Proto-IE: *yewə- (Gr zd-) Meaning: a k. of cereals: Hittite: ewa- n. 'eine Feldfrucht, Abart der Gerste'. Old Indian: yáva-h. m. 'barley, corn'; yávya- 'suitable for barley; m. stock of barley or fruit'; (Kafir) Ashkun, Waigali yū 'barley, millet'. Avestan: yava- 'crop', yəvīnm. 'Getreidefeld'. Other Iranian: Pers žav 'Gerste, Kurd', Baluchi žaw, žō 'barley', Yagn yau 'id.', Osset jäw 'millet'. Old Greek: zdeiá-i f., later zdeiăa, zdeẩ (zdéä) 'Dinkel, Spelt, Triticum monococum', zdéi- dōro- 'Spelt (Getreide)', zdeó-pū ro-n 'Art Triticum', LS: Hom. phüsízdoo- as epith. of earth, prob. 'producing' dzéa, âia , but reinterpreted as from zdōā' (zdóā) 'producing life' Aesch., etc. Slavic: *jevīnъ, *jevьnjā (блр. ёy̆ня), *jevъdь (Rus dial. новг., пск., осташк. о́водь, ово́дь 'яровая рожь' Dictionary of Russian folk dialects 22:301). Baltic: *jav-a- c., *jaû-ja- c., *jaû-jầ (1) f. Celtic: OIr eorna 'Gerste'. Russ. meaning: растение (какой-то злак).

Proto-IE: *k(w)Als- Meaning: ear (of cereals): Slavic: *kolsъ. Albanian: kallí, pl. -nj

m. 'spike';? káshtë 'straw'. Russ. meaning: колос.

Proto-IE: *sas- Meaning: cereals: Old Indian: sasyá- 'corn, grain, fruit', sasá- 'herb, grass, corn'. Avestan: hahya- 'Getreide'. Celtic: Gaul acc. (s)asiam Roggen ("secale Taurini sub Alpibus asiam vocant” Plin. H.N.); Cymr haidd 'hordeum', Bret heiz 'orge'. Russ.

meaning: растение (злаки).

Proto-IE: *ad- <PIH *H-> Meaning: cereals: Hittite: hattar n. 'ein Getreide', Lyk.

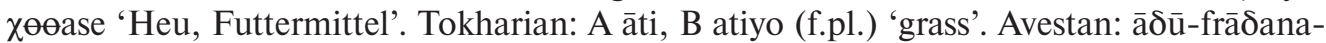
'grain-abundant'. Armenian: hat 'grain'. Germanic: *at-isk-a- m. Latin: ador, gen. -oris/ öris n. 'Art Getreide, Spelt'. Russ. meaning: растение (зерно, зерновой злак).

Proto-IE: *d ${ }^{\mathrm{e}}$ rət-, ${ }^{*} \mathrm{t}^{\mathrm{e}}$ red- Meaning: a k. of wild cereal: Old Greek: tórdūlo-n n. 'hartwort, Tordylium officinale' Ruf. ap. Orib., Gal; tordylon Plin. Baltic: *dî̂s-â f., -iã f. Germanic: *dúrø-u- c., *өurt-u- c. Russ. meaning: растение (дикорастущий злак). 
Proto-IE: *gAnt- Meaning: a k. of cereals: Hittite: kant- c. 'Weizen', Lyk. $\chi$ ada'Getreide'. Tokharian: B kanti 'bread'. Avestan: gantumō 'Weizen'. Other Iranian: NPers. gandum 'Weizen'. Russ. meaning: злак.

Proto-IE: *pūr- Meaning: wheat, spelt; couch-grass: Old Indian: pūra- m. 'a sort of unleavened cake fried with ghee or oil', pūrikā f. 'a sort of cake'. Old Greek: pūró-s, pl. pürói, dor. spüró-s 'Weizenkorn, Weizen'; pürèn, -ênos m. 'Obst-, Fruchtkern'. Slavic:

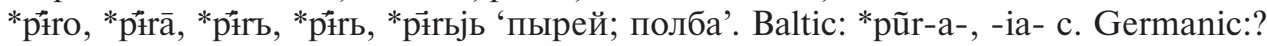
*fúrs-a- m. Russ. meaning: растение (злак - пшеница; пырей).

Given that "Of the three "core" and two "peripheral" hypothetical branches of Nostratic, three are most definitely traced back to protolanguages whose speakers practiced at least some form of agriculture, namely, Indo-European..." (Starostin 2017), I will be grateful to any reader who finds in this set of nine Proto-Indo-European terms at least one, indicating anything different from "the near-complete lack of terms for cultural plants with unambiguously determined semantics", or an absolutely different, as opposed to the cited Afro-Asiatic comparisons, "degree of semantic lenience and topological scattering" (Ibid.).

It is interesting why this semantic inconsistency in the names of cereals in IndoEuropean points to the fact that the "speakers practiced at least some form of agriculture", while Proto-Afro-Asiatic reconstruction is expected to have "at least several terms... with specifically agricultural semantics either directly matching across lineages or at least relatable to each other through trivial, typologically common semantic shifts (e.g. ... 'wheat' - 'grain /of wheat/', etc.)" (Ibid.)

But I see inconsistency in a different aspect: how can one reconcile the following two statements:

First, the cultural vocabulary as a whole is less stable, i.e. the words that do not belong to the basic layer, as a rule, have a shorter "life cycle" and are replaced by lexical innovations much faster. Accordingly, for example, the a priori probability that the same word with the meaning "war" or "club" will remain unchanged (except for the phonetic appearance) for five or even more than ten thousand years, even in one language (not to mention more), should be much lower than for the word "hand" or the pronouns "I" and "thou". One can expect various semantic shifts for such words at best, and complete disappearance at worst. Exceptions are, of course, possible, but in general, only an incurable optimist can count on a successful reconstruction of a full-fledged corpus of cultural vocabulary at the level of, say, 10th-12th thousand BC. (G. S. Starostin's comment to my article).

... the archaeological data do not allow us to reconstruct in any reasonable detail the social organization of the 'Natufians,' nor their system of beliefs, not to mention things like music and rituals. A mere introduction of comparative linguistic data makes it possible to significantly refine our reconstruction of this culture. When we turn to comparative linguistic data, we find out that Afroasiatic Urheimat may be localized in space and time with the area and lifespan of the Natufian culture (Militarev 2000; Starostin 2000; Ember et al. 2006). The application of comparative linguistic methods allows us to reconstruct the vocabulary of the carriers of the proto-Afroasiatic language, that makes it possible to identify a set of terms denoting the realities of family organization, political attitudes, beliefs, etc. (Militarev 1990, 2000, 2002, 2004) (Korotayev et al. 2019: 1).

I believe, this discrepancy of these two opposite statements is perfectly explained by a very apt phrase "incurable optimist", which describes all of us studying distant kinship of languages, including G.S. Starostin himself, combining the uncombinable but the only possible approach. I mean critical and skeptical attitude to what we do and what even our most skilled colleagues do, without which serious science would not have existed, and "incurable optimism", without which we would have worked only on mainstream safe and reputable subjects with predictable results or minor local problems that are necessary but have little to do with serious scientific progress and real breakthroughs. Without "incurable 
optimism" Moscow school of comparative linguistics (and many other research areas in any science that are ahead of time) would not have existed or would have ceased to exist long time ago.

\section{Comments by A. V. Dybo and my responses.}

AD: There is no abstract meaning of "war" similar for different languages (and protolanguages) $<\ldots>$ the statement "in all the languages both dead and living, the term "war" is usually distinguished from the terms "struggle", "skirmish", "plunder", "raid", and others located in the same semantic field" does not seem reasonable.

AM: I agree that there is no abstract meaning of "war" that is similar for different languages (and ancestor languages), but in many languages there is the term "war" that is different from terms of the same semantic field of the language in question: "fight", "confrontation", "robbery", "raid", etc. Our notion of it is based on existing material: if in a certain language in certain sources this word is translated only as "war" and not as "war, fight" or "war, raid", then the actual polysemy of lexemes remains a purely theoretical knowledge, which is only hypothetically applicable to this case. And of course this term with the only registered meaning of "war" could and can have metaphorical and context dependent variants; however it is highly improbable that, for example, an informant who understands English would answer a question "how do you say "war" in your language?" by giving a word meaning "fight", "competition" or even "battle", and the person asking the question would register it as "war" without trying to get the informant to understand the question. And if there are several informants speaking the same language, or the same term for war is registered according to informants speaking different cognate languages and demonstrates regular phonetic correspondences in these languages, then will it make sense to suggest that different informants understood the word war not in its main meaning, and different investigators all failed to notice it? By main meaning I mean that meaning of "war" that in case of any polysemy is registered under No. 1 in a dictionary (in Russian it is "война", in Dahalo it is ${ }^{m}$ bốri), i.e. something like: organized armed fight consisting of a series of battles between opposing parties, involving significantly more fighters than single conflicts; this definition is not exhaustive and not inarguable like definition of any complex event, but I think it is clear to everyone.

AD: At the same time, in order to make historical implications, one must nevertheless differentiate between the meanings "war $=$ a sequence of armed conflicts between societies (= organized groups of individuals) where intentional slaughters can occur", "battle = fray =a single armed conflict between societies, where intentional slaughters can occur", and "combat $=$ a single armed conflict between individuals or societies where intentional slaughters can occur", and also "struggle = conflict between individuals or societies", "fight = a single conflict between individuals or societies, in which attempts to inflict injury may occur," etc.

AM: The fact is that the idea that inspired me to do this micro research was not so much to tell war from not war in prehistory and not to have scholastic classification disputes over the issue of which conflict may be considered a war, but rather to put trust in those who speak or spoke these languages and supposedly their ancestor languages: they meant something by this term translated as "war" into European languages in bilingual dictionaries, by differentiating it from other terms defining similar phenomena.

AD: ... in order to restore meaning of a certain reconstructed lexeme, as well as to register true interpretation of the lexeme in a dictionary of the language under consideration, we need to establish both the micro-system of lexemes that includes this lexeme and which semantic characteristics work as distinctive ones in this micro-system. To do that for an ancestor language, it is necessary to define relevant micro-systems and their distinctive characteristics for at least a part of compared languages (usually, in order to do it correctly, 
one needs to establish diagnostic contexts of usage of these words, which requires either a targeted poll... or a sufficiently large corpus of texts in the language).

AM: No one questions that all of this is necessary. And it is great that higher semantic comparison standards are developed in comparative linguistics and in historical typology of semantic changes. However, it would be a significant exaggeration to say that at the present level of comparative studies these standards (that seem to be developed by Russian linguists only) have significant influence on them. Besides, try to "define relevant micro systems and their distinctive characteristics", as well as "establish diagnostic contexts of usage of these words", let alone conduct "a targeted poll" or find "a significantly large text corpus in the language" when we talk about lots of languages without written form like Chadic or Omotic languages! It is possible for Semitic languages, but Semitic material arouses the least amount of criticism. Moreover, language science has not yet reached such level of synthesis, when the same linguists methodically develop higher semantic comparison standards and at the same time (considering dramatic lack of qualified specialists in any language family apart from IndoEuropean) work on rather deep reconstruction of ancestor languages. A.V. Dybo, alas, seems to be a fortunate exception to the rule. Solution? Do not address insolvable problems in dreaming expectation that one day someone will succeed in applying reliable semantic descriptions to words of all languages and creating semantically reliable etymologies for these words, as well as ancestor language reconstructions at all levels? Perhaps... It is a pity I will not live to see this beautiful era... Speaking seriously, considering the ever decreasing public and governmental interest in liberal arts globally and demand for them, I have one (little) hope for neural networks, using which a handful of advanced IT specialists, coincidentally being linguistics enthusiasts (like great physicist M. Gell-Mann was!), will manage to solve linguistic problems we failed to solve. If there is someone who will be able to do my work better, I will be happy. But not to address issues that are not mainstream or ignored by it, even with imperfect tools and lots of blind spots, I, honestly speaking, find boring.

$\mathrm{AD}:$... the number of words from military field reconstructed for the Proto-IndoEuropean strate (fifth millennium BC) with a certain degree of reliability (29 words) is comparable to the amount recovered for the Proto-Afroasiatic (tenth millennium BC; 24 words). But, as we tried to show, the selection into the Proto-Indo-European vocabulary is performed by several orders more thoroughly...

AM: It would have been strange, if the situation was different, considering how many millennia Proto-Indo-European is closer to our time, how many centuries serious IndoEuropean linguistics is older than serious Afro-Asiatic linguistics, and how many times the number of Indo-European comparative linguists and etymologists in the world (there are, probably, thousands of them) is higher than that of Afro-Asiatic linguistics scholars - those who are not occupied with conjunction $\mathrm{X}$ in language $\mathrm{Y}$ (which, of course, is also important in a way) and not with field linguistics (without which our science would not have existed), but who really do comparative Afro-Asiatic linguistics, who establish phonetic correspondences, create new etymologies and classifications or improve the existent ones, and make proto-language reconstructions reliable to the extent possible at today's level, etc. I am going to tell you in confidence how many of them there have been in the world, say, for over the past two decades after demise of I. M. Diakonov: five (!) - Aharon Dolgopolsky, Olga Stolbova, Václav Blažek, Gabor Takács and yours truly, of whom only the last four are alive. Moreover, even the youngest two of these four can hardly be called today middleaged. And it is possible that tomorrow there will not be anyone left. In a preliminary (nonpublished) version of his review, G. S. Starostin called me "one of the top Russian specialists in historical Semitic and Afro-Asiatic linguistics". If we talk Afro-Asiatic linguistics only, it would me more accurate (and less complimentary) to call me "one of the two Russian specialists in comparative Afro-Asiatic linguistics".

That is why, what I have been doing to the best of my ability in Afro-Asiatic linguistics for many years is either paving the way for or slightly opening those lines of research, with 
regard to which (apart from comparative Semitic) I have a tiny hope that someone someday will continue and develop them, namely: root variants (without singling them out it is difficult to establish regular consonantal correspondences); compatibility (and variability) of consonants in Semitic roots; compiling Semitic etymological dictionary (together with L.E.Kogan), Afro-Asiatic etymological database (together with O.V. Stolbova) and AfroAsiatic lexicostatistical database; establishing new and specifying the established AfroAsiatic sound correspondences; determining root extensions and fossilized affixes in AfroAsiatic; genetic classification and glottochronology; selective etymologization and reconstruction of significant cultural terms; problem of the Afro-Asiatic macrofamily borders; its lexical contacts on both continents; search for its Urheimat; attempts at coordinating linguistic data with archaeology and genetics, etc. If the situation with my field of science were not so lamentable, it would have been more reasonable to focus on the most important lines of research (etymological dictionaries, glottochronology?) and bring them up to a desired level. Although I still note, it is not realistic to expect from a tiny group of Afro-Asiatic linguists to found "the city on a marshland" with the level of skills approaching Indo-European linguistics, countless modern architects of which add exquisite fine decoration to a nearly finished grand temple ${ }^{12}$.

\section{Notes}

${ }^{1}$ Examples from a book containing exceptionally valuable lexical material and a lot of far-fetched and fantastic etymologies: Ehret 1980.

${ }^{2}$ All examples are from: Blench 2018.

${ }^{3}$ See: Militarev, Nikolaev 2020, as well as a paper prepared for publication (Journal of Language Relationship, 2021): Militarev A., Nikolaev S. Proto-Afrasian Names of Other (Non-Ungulate) Animals in Light of the Proto-Afrasian Homeland Issue.

${ }^{4}$ Several examples see in: Militarev 2020a.

${ }^{5}$ My attempt to connect archaeology, genetics, Biblical history, Ethiopic written tradition and glottochronology see in: Militarev 2018.

${ }^{6}$ Semit. *kalb- with the fossilized suffix - $b$ (c.f., however, $-m b$ - in West Rift) is traced back to PAA $*^{*} k^{w}(h V) l$ - > Sem.: Gz. $k^{w a ̈ h i l a ~ " f o x-l i k e ~ a n i m a l " ; ~ B e r b .: ~ A y r ~ a ̆-k u ̂ l e n ~ " l o u p " ~ a n d ~ o t h e r ; ~ C h a d . ~ C .: ~}$ Bura kila, Gvoko kale, Mbuko kaĺá, Buduma kali, Logone kle "dog" (<*kVr- in O.V. Stolbova 2016: $\# 455$, but cf. "Ch ${ }^{*}-l$ - is mostly preserved as such in Ch languages in CVIV roots"; ibid.: 44), E.: Dangla kùlkò "cynhyène"; Cush. C.: Waag kuli "dog", S.: Iraqw, Gorowa kalaamb-aytú "honey badger(s)".

${ }^{7}$ There is only one, but strong argument supporting the assumption of such a route: in his remarkable Omotic dictionary (Bender 2003) L. Bender quotes a breath-taking example, which could have been taken for eccentric mystification, if not for the solid reputation of the author: the word "god" in the North Omotic language Gimirra (Bench) is conveyed as garamantči (L. Bender himself, possibly, did not understand the meaning of his discovery, in any case, he did not comment on it).

${ }^{8}$ Arguments see in: Militarev 1991; Militarev 2020b.

${ }^{9}$ A Hadza Lexicon (ms) / Ed. Kirk Miller, with M. Anyawire, G. G. Bala, B. Sands. 2013. P. 118. I take this opportunity to thank Kirk Miller for sharing this work with me.

${ }^{10}$ All examples are from: Jungraithmayr, Ibriszimow 1994.

${ }^{11}$ And the whole set of Cushitic roots, which were probably borrowed by Ethio-Semitic languages

rather than the other way around: Cush. C.: Bilin šinrây; E.: Saho sinrâ, Afar sirrây, Somali saren, Harso soro "wheat", Hadiya sara-ta "sorghum" (all are supposedly traced back to common protoform *Sar-n-ay "wheat").

${ }^{12}$ This is on the one hand. And on the other... No matter how hard I try I cannot see a "way more thorough" selection into Proto-Indo-European vocabulary using stricter criteria of semantic comparison and reliable semantic description in such examples provided by A. V. Dybo (perhaps, of course, she did not provide the whole material) as:

PIE * $g^{w}$ eru "spear staff": Lett. verū, gen. verus, pl. verua n. "skever", Umbr. berus "verubus", berva "verua" "skewer, spear"; Old Irish biur "spear, skewer", Welch ber "spear, skewer"; Ind.-Iran. Avest. grava- $<{ }^{*} g^{w}$ rewo- "staff". 
PIE * ghais-o/e-s "throwing spear, dart” including Old Greek khâio-s m., khâio- $n$ n. "shepherd's crook".

PSIE *dus-menēs "hostile", Old Greek dusmenē's "hostile", Av dušmanah- "hostile", Skt durmanās "sad".

PNIE *lau- "spoils (military or hunting)": Lat. lucrum $(<* l u-t l o-m)$ "gain, advantage"; Old Irish lóg "earnings, price"; OHG lōn "compensation, payment" (Germ. Lohn), Goth. laun "payment", cf: Old. Slav. lovü "spoils of the chase, catching".

\section{References}

Bender, M.L. 2003. Omotic Lexicon and Phonology. In Aethiopica: International Journal of Ethiopian and Eritrean Studies. Carbondale: 165. https://doi.org/10.15460/aethiopica.10.1.216

Bergström, A., et al. 2020. Origins and Genetic Legacy of Prehistoric Dogs. Science 370 (6516): 557564.

Blench, R. 2006. Archaeology, Language, and the African Past. Lanham: Altamira Press.

Blench, R. 2018. The Peopling of the Canaries: New Data and New Hypotheses. Cambridge.

Cavalli-Sforza, L.L., P. Menozzi, and A. Piazza. 1994. The History and Geography of Human Genes. Princeton: Princeton University Press.

Clutton-Brock, J. 2017. Origins of the Dog: The Archaeological Evidence. In The Domestic Dog: Its Evolution, Behavior and Interactions with People, edited by J. Serpell, 7-21. Cambridge: Cambridge University Press. https://doi.org/10.1017/9781139161800.002

Dayan, T. 1994. Early Domesticated Dogs of the Near East. Journal of Archaeological Science 21 (5): 633-640.

Ehret, C. 1980. The Historical Reconstruction of Southern Cushitic Phonology and Vocabulary. Berlin: Reimer.

Ehret, C. 1995. Reconstructing Proto-Afroasiatic (Proto-Afrasian): Vowels, Tone, Consonants, and Vocabulary. Berkeley: University of California Press.

Ehret, C. 2000. Language and History. In African Languages: An Introduction, edited by B. Heine and D. Nurse, 272-297. Cambridge: CUP.

Ehret, C. 2001. A Historical-Comparative Reconstruction of Nilo-Saharan. Köln: Rudiger Köppe.

Ember, M., C. R. Ember, P. N. Peregrine, and S. Starostin. 2006. Cross-Cultural Research as a Rosetta Stone for Discovering the Original Homelands of Protolanguage Groups. Cross-Cultural Research 40 (1): 18-28.

Fleming, H.C. 2006. Ongota: A Decisive Language in African Prehistory. Wiesbaden: Harrassowitz Verlag.

Jungraithmayr, H., and D. Ibriszimow. 1994. Chadic Lexical Roots. Vol. II, Documentation. Berlin: Dietrich Reimer Verlag.

Kießling, R., and M. Mous. 2003. The Lexical Reconstruction of West-Rift Southern Cushitic. Koln: Rudiger Koppe Verlag.

Korotayev, A., et al. 2019. Evolution of Eurasian and African Family Systems, Cross-Cultural Research, Comparative Linguistics, and Deep History. Social Evolution and History 18 (2) 286-312.

Militarev, A. 1990. Afrasian Cultural Terms (Preliminary Report). In Proto-Languages and ProtoCultures, edited by V. Shevoroshkin, 33-54. Bochum: Brockmayer.

Militarev, A. 1991. Garamantida v kontekste severoafrikanskoi istorii. Sud'ba odnogo naroda glazami lingvista [The Garamantide in the Context of North African History: The Fate of a People through the Eyes of a Linguist]. Vestnik drevnei istorii 3: 130-158.

Militarev, A. 2000. Towards the Chronology of Afrasian (Afroasiatic) and Its Daughter Families. In Time Depth in Historical Linguistics, edited by C. Renfrew, A. McMahon, and L. Trask, 1: 267307. Cambridge: The McDonald Institute for Archaeological Research.

Militarev, A. 2002. The Prehistory of a Dispersal: The Proto-Afrasian (Afroasiatic) Farming Lexicon. In Examining the Farming/Language Dispersal Hypothesis, edited by C. Renfrew and P. Bellwood, 135-150. Cambridge: The McDonald Institute for Archaeological Research.

Militarev, A. 2004. Another Step towards the Chronology of Afrasian (I). Babel and Bibel 1: 282-333.

Militarev, A. 2005. Root Extension and Root Formation in Semitic and Afrasian: Proceedings of the Barcelona Symposium on Comparative Semitic, 19-20.11.2004. Aula Orientalis 23 (1-2): 83-130.

Militarev, A. 2018. Nemeinstrimovskie soobrazheniia po povodu bibleiskogo povestvovaniia o "synakh Izrailia" v Egipte (o vozmozhnostiakh sravnitel'no-istoricheskogo yazykoznaniia v rekonstruktsii etnokul'turnoi istorii) [Non-Mainstream Considerations by a Comparative Linguist about the 
"Sons of Israel" in Egypt (On the Possibilities of Comparative Historical Linguistics in Reconstructing Ethnocultural History)]. Researchgate. https://www.researchgate.net/publication/326066236 Predvaritelnaa_versia

Militarev, A. 2020. Libyo-Berbers - Tuaregs - Canarians: Linguistic Evidence. Études et Documents Berbères 43: 131-158.

Militarev, A. 2020. Inscriptions in Libyan Script in the Libyan Desert and the Island of Ferro:

Background and Experiment in Reading. Études et Documents Berbères 44: 57-108.

Militarev, A., and S. Nikolaev. 2020. Proto-Afrasian Animal Names and the Problem of ProtoAfrasian Urheimat. Journal of Language Relationship 18 (3): 199-226.

Starostin, G. 2017. Macrofamilies and Agricultural Lexicon: Problems and Perspectives. In Language Dispersal Beyond Farming, edited by M. Robbeets and A. Savelyev, 123-154. Amsterdam: John Benjamins Publishing Company.

Starostin, S.A. 2000. Comparative-Historical Linguistics and Lexicostatistics. In Time Depth in Historical Linguistics, edited by C. Renfrew, A. McMahon, and L. Trask, 1: 223-266. Cambridge, UK: The McDonald Institute for Archaeological Research.

Takács, G. 2008. Etymological Dictionary of Egyptian. Vol. III. Leiden: Brill. 